[DOI: 10.24214/jecet.A.8.4.39195.]

Jaurnal of Environmental Science, Computer Science and Engineering \& Technology

An International Peer Review E-3 Journal of Sciences and Technology

Available online at www.jecet.org

Section A: Environmental Science

Research Note

\title{
Impact of Environmental Degradation on Real Estate Investment in Niger Delta Region
}

\author{
Ekenta Chukwuemeka \\ Department of Estate Management, Rivers State University, Port Harcourt, Nigeria \\ Received:25September 20198; Revised: 04 October 2019; Accepted: 10 October 2019
}

\begin{abstract}
Environmental Degradation has posed serious challenges on real estate investment in Niger Delta and Nigerians in general. This study examines the negative effects of environmental degradation on real estate investment as it applies to Niger Delta Region. Data for the study were collected through cross-sectional survey and documentary analysis of records on real estate investment and environmental degradation. The paper also examined the negative effects of environmental degradation on real estate investment in the study area. It is based on this premise that useful suggestions were made.
\end{abstract}

Key words: Investment, Real Estate, Environment and Degradation.

\section{INTRODUCTION}

It is a well known fact that the Niger Delta Region is the richest part of Nigeria in terms of natural resources. The area has large oil and gas deposits, as well as extensive forests, good agricultural land and abundant aquatic resources. Despite the tremendous natural and human resource base, the region's potential for sustainable development remains unfulfilled and its future is being threatened by environmental degradation and deteriorating economic conditions which are not being addressed by government policies and actions.

The question that is likely to agitate the minds of real estate investors is whether or not real estate is an investment succor to many of them that have previously lost huge sums of money due to environmental degradation. This paper is therefore posed to examine the negative effects of environmental degradation in Niger Delta, with a view to improving and sustaining real estate investment in the study area. 
Objective of the Study: The objective of this study is to examine the negative effects of environmental degradation on real estate investment in the study area as well as making suggestions on the options for sustainable development within an integrated coastal zone management framework.

\section{REVIEW OF RELATED LITERATURE}

2.1. Real estate: Real estate refers to land and building fixed, immovable, or permanently attached to it such as appurtenances, buildings, fences, fixtures, improvements, roads, shrubs and trees (but not growing crops), sewers, structures, utility systems, and walls. Title to real estate normally includes title to air and surface rights which can be bought, leased, sold, or transferred together or separately, this is also called real property.

2.2. Investment: According to Ekenta $^{1}$ (2014), investment is the utilization of money or other valuable resources in such a way as to guarantee a regular flow over a period of time or the appreciation and/or the recouping of a specified lump sum on a future date in consideration for the utilized resources and risk taken. This invariably raises the fact that real estate investment is the employment and application of a capital sum in land in expectation of a return either in the form of a recurring income or in the form of a gain due to an appreciation of a return either in the form of a recurring income or in the form of a gain due to an appreciation in value or both ${ }^{2}$ (Ekenta $\&$ Kalu, 2016).

2.3. Environmental Degradation: Environmental degradation is the deterioration in environmental quality from ambient concentrations of pollutants and other activities and processes such as improper land use and natural disasters. It could also be referred to as the deterioration of the environment through depletion of resources such as air, water, and soil, the destruction of ecosystems and the extinction of wildlife ${ }^{3}$ (Eregha \& Irughe, 2009). Environmental degradation can occur naturally, or through human process.

According to Aluko ${ }^{4}$ (2004) in his study on environmental degradation and its impact on the Niger Delta region used primary data sourced from thirteen communities in the area employed descriptive analysis. He concludes that oil exploration activities in the region leading to environmental degradation are responsible for the high degree of poverty in the area. This study was based on one of the economic effects of environmental degradation.

\subsection{Adverse effects of environmental degradation on real estate investment:}

a) Ozone Layer Depletion: Ozone layer is responsible for protecting the earth from harmful ultraviolet rays. The presence of chlorofluorocarbons; hydro chlorofluorocarbons in atmosphere is causing the ozone layer to deplete. As it will deplete it will emit harmful radiations back to the earth. Ozone layer depletion will cause many materials to degrade faster. These materials include PVC and other building materials of commercial interest.

b) Economic Loss on Returns: The huge cost that a country may have to borne due to environmental degradation can result to huge economic loss in terms of restoration to green cover, cleaning up of landfills and protection of endangered species. The economic loss can also result to loss of returns from real estate investments, especially the tourism sector.

c) Poverty: The poverty in the Niger Delta region is attributed to poor crop harvests and lack of quality natural resources that are needed to satisfy basic survival needs. Most vulnerability situations brought about by water shortages, climate change, and poor crop yields in 
developing countries are tied to environmental degradation. Hence, the lack of access to adequate basic needs such as water and food directly induce poverty.

d) Scarcity of Natural Resources: Environmental degradation through aspects such as over exploration of natural resources, pollution, and deforestation can contribute to the scarcity of resources particularly arable land, water, genetic resources, medicinal plants, and food crops.

e) Water Pollution and Water Scarcity: Water scarcity compounds health problems; water pollution leads to declining fisheries and acquisition leading to irreversible compaction

\section{METHODOLOGY}

A cross-sectional survey was conducted. The survey questionnaire designed was distributed randomly amongst 200 residents from 20 communities within the Niger Delta region. 185 questionnaires were retrieved from the study (giving a response rate of 92.5\%) with 5\% margin of error and 95\% confidence level, while descriptive statistics was used to profile the responses from respondents. Further, the Relative Importance Index (RII) was used to rank the negative impacts of environmental degradation on real estate investment by respondents.

RII is calculated as;

$\mathrm{RII}=(4+3+2+) / 4 \mathrm{~N}$

Where;

$$
\begin{aligned}
& =\text { Strongly Agree }(\mathrm{SA}) \\
& =\text { Agree }(\mathrm{A}) \\
& =\text { Disagree }(\mathrm{D}) \\
& =\text { Strongly Disagree }(\mathrm{SD}) \\
& \mathrm{N}=\text { Number of Respondents }
\end{aligned}
$$

The Study Area: The Niger Delta region is the delta of the Niger River sitting directly on the Gulf of Guinea on the Atlantic Ocean in Nigeria. It is typically considered to be located within nine coastal southern Nigerian states, which include: all six states from the south-south geopolitical zone, one state (Ondo) from south-west geopolitical zone and two states (Abia and Imo) from south-east geopolitical zone.

The region is dominated by rural communities that depends solely on the natural environment for subsistence living. More than seventy percent of the people depend on natural environment for living and non-living livelihood ${ }^{5}$.

By virtue of its nature, the region is endowed with rich natural resources such as oil (which it is globally known for), abundant flora and fauna, hydrocarbon deposits in its oil, clay for burnt brick, silica sand for glass manufacturing industries, infact, its rich mangrove forest was considered the third largest in the world. The primary occupations of the people include fishing, farming, forest products gathering, and crafts with forest products which are done at subsistence levels, basically to keep body and soul together. 


\section{RESULT}

The findings revealed that environmental degradation adversely affects real estate investments in Niger Delta region. This is done through some identified variables as shown in table $\mathbf{1}$ below.

Table 1: Effects of Environmental Degradation on Real Estate Investment in Niger Delta.

\begin{tabular}{|c|c|c|c|c|c|c|c|}
\hline $\mathbf{S} / \mathbf{N}$ & STATEMENT & $\mathbf{S A}$ & $\mathbf{A}$ & D & SD & TOTAL & RII \\
\hline 1 & $\begin{array}{l}\text { Ozone layer depletion cause fast } \\
\text { degradation of building materials }\end{array}$ & $\begin{array}{c}61 \\
(33 \%)\end{array}$ & $\begin{array}{c}79 \\
(42.7 \%)\end{array}$ & $\begin{array}{c}33 \\
(17.8 \%)\end{array}$ & $\begin{array}{c}12 \\
(6.5 \%)\end{array}$ & $\begin{array}{c}185 \\
(100 \%)\end{array}$ & 0.755 \\
\hline 2 & $\begin{array}{l}\text { Environmental degradation, has led } \\
\text { to loss of real estate investment } \\
\text { returns }\end{array}$ & $\begin{array}{c}40 \\
(21.6 \%)\end{array}$ & $\begin{array}{c}107 \\
(57.8 \%)\end{array}$ & $\begin{array}{c}15 \\
(8.1 \%)\end{array}$ & $\begin{array}{c}23 \\
(12.4 \%)\end{array}$ & $\begin{array}{c}185 \\
(100 \%)\end{array}$ & 0.722 \\
\hline 3 & $\begin{array}{l}\text { The high rise of poverty in Niger } \\
\text { Delta is as a result of environmental } \\
\text { degradation }\end{array}$ & $\begin{array}{c}86 \\
(46.5 \%)\end{array}$ & $\begin{array}{c}64 \\
(34.6 \%)\end{array}$ & $\begin{array}{c}18 \\
(9.7 \%)\end{array}$ & $\begin{array}{c}17 \\
(9.2 \%)\end{array}$ & $\begin{array}{c}185 \\
(100 \%)\end{array}$ & 0.796 \\
\hline 4 & $\begin{array}{l}\text { Environmental pollution has } \\
\text { contributed immensely to scarcity } \\
\text { of natural resources }\end{array}$ & $\begin{array}{c}93 \\
(50.3 \%)\end{array}$ & $\begin{array}{c}52 \\
(28.1 \%)\end{array}$ & $\begin{array}{c}31 \\
(16.8 \%)\end{array}$ & $\begin{array}{c}9 \\
(4.9 \%)\end{array}$ & $\begin{array}{c}185 \\
(100 \%)\end{array}$ & 0.809 \\
\hline 5 & $\begin{array}{l}\text { Water pollution has created room } \\
\text { for depletion of aquatic lifes }\end{array}$ & $\begin{array}{c}55 \\
(29.7 \%)\end{array}$ & $\begin{array}{c}87 \\
(47 \%)\end{array}$ & $\begin{array}{c}32 \\
(17.3 \%)\end{array}$ & $\begin{array}{c}11 \\
(5.6 \%)\end{array}$ & $\begin{array}{c}185 \\
(100 \%)\end{array}$ & 0.751 \\
\hline
\end{tabular}

\section{CONCLUSION AND RECOMMENDATION}

In this paper, we have examined the negative effects of environmental degradation on real estate investment. The study has also revealed that environmental degradation in Niger Delta also contributes to a large extent on the poverty in the area. It has also been observed from the study that the Niger Delta region has suffered degradation as a result of oil and gas exploration which has led to water pollution, air pollution and land degradation from oil spillage, gas flaring and canalization.

Based on the above negative consequences, the researcher hereby recommends that;

1. Environmental laws should be made and enforced urgently through the establishment of environmental protection agency boards at both the federal, state and local government levels.

2. Government at all levels should encourage recycling as it will drastically slow down environmental degradation.

3. There is need for regular and routine sensitization to change the perception and priorities of users of environmental resources and services.

4. There should not be any form of politicization of the issues of natural resource management and governance. 


\section{REFERENCES}

1. C.Ekenta, Analysis of Socio-Economic Impacts of Nigeria's Land Reform of 1978 on Real Estate Investment in Rivers State. Unpublished Ph.D Thesis Department of Estate Management, Abia State University, Uturu,2014.

2. C. Ekenta, and I.U.Kalu, Socio-Economic Factors Affecting Accessibility to Land for Real Property Investment in Obio/Akpor L.G.A. Nigeria. Journal of Scientific and Engineering Research.2016, 3(2): $119-124$.

3. P.B.EreghaandI.R.Irughe, Oil Induced Environmental Degradation in the Nigeria's NigerDelta: The Multiplier Effects. Journal of Sustainable Development in Africa.2009, 11(4): 161-175.

4. M.A.O.Aluko, Sustainable Development, Environmental Degradation and the Entrenchment of Poverty in the Niger Delta of Nigeria. Journal of Human Ecology 15(1): 63 - 68 .

5. United Nation's Development Report (UNDP). (2006). Niger Delta Development Human Report.

* Corresponding Author:Ekenta Chukwuemeka

Department of Estate Management, Rivers State University, Port

Harcourt, Nigeria 